\title{
Analysis Influence Of Teacher Empowerment Performance Within Improving The Quality Of Education In Elementary School In Surabaya City
}

\author{
Dr. Waspodo Tjipto Subroto, \\ M.Pd Lecture of State University of Surabaya
}

\begin{abstract}
Teachers have importance posision for increase of quality in procedural learning, so the performance of the teacher must be increase of activity for learning. Impowering of teachers for improvement to the performance of teachers is visible to increase of quality at elementaryschool in Surabaya City. Empowering Teachers in educated qualification, training and briefings for the teacher's performance to quality education at elementary school in Surabaya City. The influence of qualification education, training and briefings for teachers can be a increase of performance and quality of learning and teaching. Also the influence of teachers performance to increase of education quality in elementary school.

This research is intended to study how does the implementation of empowerment for teachers (education qualification, training and briefings) conducted to increase of education quality. The research is conducted to the sample of 174 small clusters by using stratified cluster sampling technique.

Applying structural equation modeling analysis, the research-intensive as the Findings That Followed. Result of this reasearch, education qualification of teacher influenced to teachers performance and also influenced to quality education at elementary school. And than, influenced education in service training to teacher's performance and also influenced to education quality. Next, teachers professional training to teachers also influence performance, and influence to education quality.

Conclution of this research, empowerment of teachers influence the increase of performance with indicators of knowledge, attitude and skills influenced to increase of education quality. Quality of elementary school with an indicator value increase of quantity and quality of learning.
\end{abstract}

Key Words: Teacher Impowering, performance, quality education

\section{Introduction}

Government's efforts against the government of teachers has actually been done by the Government of Indonesia Republic, through various forms of policy. Enactment of UU No. 14 / 2005 about teachers and lecturers are the basis of policies to strength the existence of teachers as professionals, like other professions. Professional quality of teachers has always pursued, either through the provision of educational qualifications and in-service training activities, with its various forms, such as: education and training, refresher courses and involvement in various seminars to update his insights in pedagogy and academic competence. The government began to realize how strategic the role of teachers in delivering the younger generation to become human resources (HR) quality and competitive so as to realize a common prosperity. The history of civilization and progress of nations in the world us that instead of natural resources abundance of the dominant nation to usher in prosperity, but the toughness of competitiveness and excellence of science and technology is exactly what role the nation to reap welfare. Even the mastering science and technology human resources tended to use technology to master the natural resources of other nations.

Dynamic development of society is rapidly moving along with the progress of science and technology that requires all parties to adapt to changes that occur in the community. Advancement of science and technology has given rise to a new paradigm for success, namely the competition. Challenges of increasingly keen competition in the era of globalization requires increased quality and efficiency of the profession an on going basis, so that competitiveness can be more competitive professionals. Era of globalization change the nature of the work of amateurs toward professionalization in all areas and aspects of life. Included in the global change is the teaching profession. In accordance with the changing demands of global society, teachers are also required professional task in the field (Education International, 1998: 112). Professional teachers rather than as tools for transmitting culture to culture but to transform it into a dynamic cultural direction and requires mastery of science and technology, high productivity and quality of work that could improve competitiveness.

Adequate educational development investments will be able to move the local economy with a large multiplier effect through school construction, procurement and maintenance of education infrastructure, and increasing teacher quality. Quality public, not just able to size every available job opportunities through investment, but also able to create new jobs. Moreover, the problem of education is a cross-sectoral issue, so 
there must be commitment from all parties, especially the education policy makers to take policy-oriented quality education quality. For policies to improve education quality high if addressed consistently, will produce graduates who are competent, who finally is able to produce competitive citizen role in large numbers.

Educational programs to improve the quality of human resources becomes very important because many of the problems found in government institutions, community institutions and activities in the community that its effectiveness depends on the quality of human resources, both in intellectual ability and moral integrity in its responsibility to society. Human resources, according to Damanhuri (2004) is one key factor in moving towards prosperity. Creating quality human resources and skills as well as highly competitive, the demands of development towards prosperity. Economic globalization is a process of economic and trade activity that brings together market forces increasingly integrated for efficiency and enhance competitiveness.

The low human development index Indonesia has had an impact on the competitiveness of the nation's declining ability of Indonesia. Deterioration of competitiveness is derived from the quality of education in Indonesia is still low. The low quality of education of Indonesia affected by several components supporting the education process, among others: the quality of teachers, learning tools such as textbooks, instructional media, learning resources and learning laboratory equipment that has not been adequate. The lack of educational support component is influenced by the lack of allocation of education funds are sourced from the State Revenues and Expenditures Budget (APBN) as well as donations from the public education (parents). The teacher's role is very important in improving the quality of education in Indonesia so that UU No 14/2005 on Teachers and Lecturers Article 8 asserts that teachers must have academic qualifications, competency certificates, educators, and healthy physically as well as having the ability to realize the goal of national education. To improve the quality of teachers, the Education Office in cooperation with the State University of Surabaya (Unesa) has organized a partnership to update the competence of teachers through refresher education (Continuing Education). According Sahudi (2009) implemented this program because the competence of teachers in Surabaya has not been optimal. Even been described by Masruri (2009) state schools in general are still apprehensive. Whereas the development of education in the city of Surabaya as a metropolitan city so rapidly, when capacity is inadequate teacher will hurt students. Other programs to improve the quality of teachers is to encourage further studies for teachers who have bachelor degree (S1) at a cost of Surabaya City Government Departement of Education, Training and Professional Teacher Education (PLPG) held by the State University of Surabaya on Elementary School teachers are also in an attempt performance empower teachers to improve the quality of the estuary profession is improving the quality of education. Further studies and a variety of training given to teachers are expected to have an impact on improving the quality of learning services that ultimately improve the quality of education.

The problems above are summarized in the formulation of the problem "How does the empowerment of teacher performance to improve the quality of education at the elementary school in Surabaya?" In the present study aims to examine the effectiveness of further study and a variety of training given to teachers in improving the quality of education at City Elementary School Surabaya. Reader Review Nation-building and nation to prosperity with the issues that continue to evolve. There are some terminology paradigm that had evolved among others: populist-based development, characterized by participatory development, human development. Today the building based on economic growth have indeed succeeded in making the wealth, but failed in realizing equitable prosperity, and even reverse many of which pose difficult problems be solved. Community development is basically emphasizing the importance of poverty indication through various empowerment of marginalized groups, namely an increase in living standards for people who lack capacity in a sustainable economy.

\section{View of Theory}

Governments are required to create and optimize human resources in various fields according to his needs. The analysis of this study based on the theory of empowerment of human resources in accordance with the need to improve the quality of education towards the creation of superior human resources and competitive begins from the improved quality performance of professional education personnel. Empowerment contains two terms, namely: (1) to give the power, transferring power, delegating authority to others, (2) to give abilities to attempt to give the ability (Oxfort Classic Dictionary). Meaning the concept of improving the quality of education has not optimize the performance of teacher empowerment, which has a role in improving the quality of education. Empowering educators embody a nuanced capacity building of human resources on empowering educators through the development of various abilities (performance) and responsibilities as well as synergistic atmosphere between government (public) with the teacher. Efforts to optimize the on going performance of teachers is an important factor than other factors in improving the quality of education. This has been recognized and implemented by the government through the assignment of further studies, a variety of training and upgrading of teachers. 
Teacher performance (Job Performance) is a result of activities that have been implemented or will be done by the teacher according to his profession as a teacher. Suman (2005) defines performance as "something done or products/ services produced or provided by someone to a group of people". Rao (Mulyasa, 2007) suggests that the performance is the result of ability and effort. Meanwhile, according to Porter (2006) that the performance is succesfull achievement role earned one of his deeds. Performance is the behavior displayed by individuals or groups. In reaching something one usually motivated by the performance. Motivation is an important element that should be owned by everyone. Because the role of motivation could serve as a spur to performance. Performance is the capacity that one has to perform or complete a job. Enterprises are the time and effort spent to achieve one's motivation. While the motivation is the hope, desire, impulse, urge to achieve something. Motivation is defined as an attitude related to interest, ability, skill, or stren gth. In connection with someone, then the motivation is intended as an ability, skill, or force someone to perform a task that becomes their responsibility. The ability of a person is basically a result of the learning process, which includes aspects of knowledge, attitudes and skills. According to Gagne (1992) learning outcomes are changes that include cognitive, attitude, and psychomotor. So also the opinion of Krathwohl (1994) which states that the learning outcomes (learning outcomes) that includes three domains, namely: (a) cognitive, (b) affective, and (c) psychomotor, which is often also called taxonomy of education objectives. Capability which includes three aspects will affect the performance of someone who in turn will affect the organization's success rate in this case the quality of education.

McClelland (2001) states that there is a positive relationship between a person's motivation and performance. This means that every worker who has high motivation to work will produce a high performance as well. Likewise, that empowerment has a positive relation to one's motivation. Techniques to motivate the performance of teachers according to Mangkunegara (2005), among others: (1) engineering needs, (2) persuasive communication techniques. Meeting the needs of teachers is an essential foundation for work behavior. Management may not be able to motivate teachers without an adequate needs. According to Maslow (2005) hierarchy of needs of teachers include: physiological needs, safety needs, social needs, esteem needs and self-actualization need

\section{Conceptual Framework and Research Hypothesis}

This study tried to uncover the role of teacher empowerment in promoting the quality of its performance in the hope of improving the quality of education in primary schools in Surabaya. Framework that has been designed in this study are as follows:

Figure: Conceptual Research

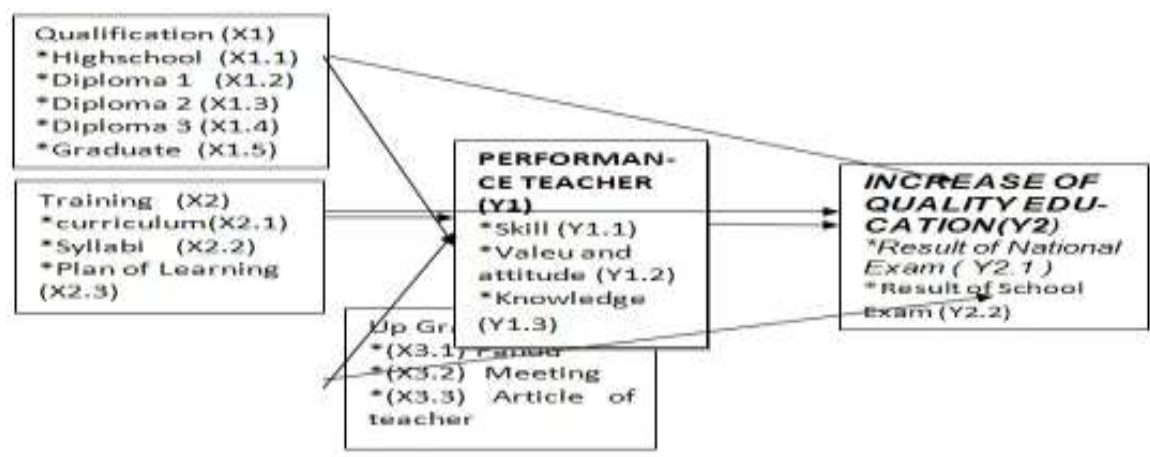

\section{Hypothesis}

Based on the background and the basic theoretical framework in this research hypothesis can be formulated as follows:

1. First Hypothesis: Increased educational qualifications of teachers, will bring significant influence to the improvement of teacher performance, among others, in knowledge, skills and attitudes to implement the learning

2. Second Hypothesis: Performance of teachers in the syllabus and learning implementation plan (RPP), implement and evaluate the learning effect on student learning outcomes improving the quality of education in elementary schools, such as: the quality of the national exam and final exam schools.

3 Third Hypothesis: Increased empowerment of the teacher's performance such as: educational qualifications, training and upgrading, will bring a significant effect on improving the quality of education in elementary schools which include: Quality of the National Examination and the School Final Examination. 


\section{Research Methodology}

Draft Research in general, this study aims to describe and analyze the effect of empowerment on improving the quality of teacher performance in primary school education city of Surabaya this as an attempt to discover, develop and test the truth of the influence of the empowerment of teachers' performance on productivity performance in an effort to improve the quality of education in primary schools. In accordance with its objectives, the study was designed as a research model explanatory, ie to explain how the role of empowerment of teacher performance in improving the quality of its performance in order to enhance productivity performance, so as to improve the quality of education in elementary school.

\section{Scope of Research.}

To focus the study, the study was limited to the empowerment of teachers in improving productivity performance in improving the quality of education at the elementary school in Surabaya. The focus of this research is to increase teacher empowerment through increased educational qualifications and training and upgrading. While the productivity performance of teachers includes the ability to develop syllabus and Learning Implementation Plan (RPP), implementing the learning and skills to guide students in intensive learning in school. Improving the quality of education embodied in the criteria for increasing the value of National Examination (UNAS) and the School Final Examination (UAS).

\section{Population and Study Sample}

Population Research The population in this study were all primary school teachers who served in the city of Surabaya, both Elementary School and Private Elementary Schools which amounted to 11.650 people spread out on 569 and 415 Elementary School Private Elementary School (Education, 2009). Research Samples Determination of the sample in this study using cluster techniques based on the area, the population of primary school teachers were divided according to sub-districts in Surabaya. Districts that serve the study site consists of 29 districts in the working area of the City Government of Surabaya. Each cluster is determined six respondents consisting of three respondents grade 6 teacher State Elementary School and 3 respondents Elementary School sixth grade teacher Private. Thus each of these clusters will be taken six district elementary school teacher as a sample to be representative of the population sub-districts, so the overall sample size of 29 × $6=174$ samples.

Data Analysis Selection of the appropriate type of data analysis is an important factor in addressing the research. To consider the issue after the proposed goals and hepotesis and data are available, then in this study used two kinds of analysis, namely: 1) descriptive analysis, and 2) multivariate regression analysis model with SEM (Structural Equation Modelling) version 4.0.

Description of Research Variables:

\section{Result and Discussion}

\section{Educational Qualification}

Table 1: Frequency Distribution of Respondents Educational Qualification

\begin{tabular}{|c|c|c|c|c|c|}
\hline No & $\begin{array}{c}\text { Education } \\
\text { Qualification }\end{array}$ & Criteria & \multicolumn{3}{|c|}{ Frequency } \\
\cline { 4 - 5 } & & & $\mathrm{f}$ & $\%$ & $\begin{array}{c}\% \\
\text { cumulative }\end{array}$ \\
\hline 1 & High school & Very Poor & 6 & 3 & 4 \\
\hline 2 & Diploma 1 & Poor & 45 & 26 & 29 \\
\hline 3 & Diploma 2 & Quite & 24 & 37 & 66 \\
\hline 4 & Diploma 3 & Good & 24 & 14 & 80 \\
\hline 5 & graduate & Very good & 34 & 20 & 100 \\
\hline & & & 174 & 100 & \\
\hline
\end{tabular}

Source: Results of Data Processing

Based on the indicators studied, it appears that at some essential things associated with: (1) undergraduate qualification S1, (2) diploma 3, (3) diploma 2, (4) a diploma, (5) Gradute. The data indicate that higher educational qualifications categorized will have an impact on the ability of teachers in developing adequate performance. With good performance will support the achievement of good work. 


\section{Training Learning}

Table 2: Frequency Distribution Training of Learning Respondents

\begin{tabular}{|c|c|c|c|c|c|}
\hline No & \multirow{2}{*}{$\begin{array}{c}\text { Education } \\
\text { Qualification }\end{array}$} & Criteria & \multicolumn{3}{|c|}{ Frekeunsi } \\
\cline { 3 - 5 } & & & $\mathrm{f}$ & $\%$ & $\begin{array}{c}\% \\
\text { cumulative }\end{array}$ \\
\hline 1 & Never & Very Poor & 6 & 3 & 9 \\
\hline 2 & Rarely & Poor & 45 & 26 & 34 \\
\hline 3 & Frequent & Quite & 24 & 37 & 65 \\
\hline 4 & More & Good & 24 & 14 & 87 \\
\hline 5 & Very often & Very good & & 20 & 100 \\
\hline & & N: 174 & & \\
\hline
\end{tabular}

Source: Results of Data Processing

Based on the indicators studied, it appears that at some essential things associated with: (1) activity in adequate training, (2) an adequate source of training materials, (3) adequate training instructor., (4) facilities supports, (5) colleagues to support. This shows that with the preparation of training syllabus and lesson plans with high category will have an impact on the implementation of learning.

3. Upgrading Professional (scientific work and innovative learning)

Table 3: Frequency Distribution of Professional Upgrading followed Respondents

\begin{tabular}{|c|c|c|c|c|c|}
\hline \multirow{2}{*}{ No. } & \multirow{2}{*}{ Up Grading } & \multirow{2}{*}{ Criteria } & \multicolumn{3}{|c|}{ Frekuency } \\
\hline & & & $\mathrm{F}$ & $\%$ & $\%$ Cumulative \\
\hline 1 & $1-3$ & Very Rarely & 6 & 4 & $4 \%$ \\
\hline 2 & $4-6$ & Rarely & 49 & 28 & $32 \%$ \\
\hline 3 & $7-9$ & Fair & 72 & 41 & $73 \%$ \\
\hline 4 & $7-9$ & Often & 35 & 20 & $93 \%$ \\
\hline 5 & 10 - more & Veri Often & 12 & 7 & $100 \%$ \\
\hline & Total: & $\mathrm{N}:$ & 174 & $100 \%$ & \\
\hline
\end{tabular}

Source: Results of Data Processing

Upgrading the data shows that with the upgrading of the categories will often have an impact on the completion of the task well, too. Upgrading is like: (1) training of scientific writings, (2) training development of instructional media (3) training of innovative learning models. With the good work it will have an impact on the achievement of high performance.

\section{Teacher Performance}

Table 4: Distribution of Respondents Frequency Performance Levels

Tabel 4: Distribusi Frekuensi Tingkat Kinerja Responden

\begin{tabular}{|c|c|c|c|c|c|}
\hline \multirow{2}{*}{ No. } & \multirow{2}{*}{ Teacher Pwerformance } & \multirow{2}{*}{$\begin{array}{c}\text { Criteria of } \\
\text { Plan }\end{array}$} & & \multicolumn{3}{|c|}{ Frekuency } \\
\cline { 5 - 6 } & & $\mathrm{f}$ & $\%$ & $\begin{array}{c}\% \\
\text { Cumulative }\end{array}$ \\
\hline \hline 1 & Very Low & $60-65$ & 13 & 7,47 & $7,47 \%$ \\
\hline 2 & Low & $66-70$ & 31 & 17,81 & $25,20 \%$ \\
\hline 3 & Self & $71-75$ & 43 & 24,71 & $49,91 \%$ \\
\hline 4 & High & $76-80$ & 74 & 42,52 & $92,43 \%$ \\
\hline 5 & Very High & $81-100$ & 13 & 7,47 & $100 \%$ \\
\hline & Jumlah : & & 174 & $100 \%$ & \\
\hline
\end{tabular}

Source: Results of Treatment

The data above show that the presence of categorized high performance will impact the work culture is also good. With a good working culture will support the achievement of good work, then it will impact on achieving high performance. 
5. Quality of Education

Table 5: Frequency Distribution of Educational Quality (value UNAS)

\begin{tabular}{|c|c|c|c|c|c|}
\hline \multirow{2}{*}{ No. } & \multirow{2}{*}{$\begin{array}{c}\text { Quality of } \\
\text { Education }\end{array}$} & \multirow{2}{*}{ Criteria } & \multicolumn{3}{|c|}{ Frekuency } \\
\cline { 4 - 6 } & & & F & $\%$ & \% Cumulative \\
\hline \hline $\mathbf{1}$ & $3-5$ & Very Low & 4 & 2,29 & $2,29 \%$ \\
\hline $\mathbf{2}$ & $5-6$ & Low & 35 & 20,15 & $22,44 \%$ \\
\hline $\mathbf{3}$ & $6-7$ & Self & 59 & 33,90 & $56,34 \%$ \\
\hline $\mathbf{4}$ & $7-8$ & High & 62 & 35,63 & $91,97 \%$ \\
\hline $\mathbf{5}$ & $8-10$ & Very High & 14 & 8,04 & $100 \%$ \\
\hline & Jumlah : & & 174 & $100 \%$ & \\
\hline
\end{tabular}

Source: Results of Data Processing

Based on the indicators studied, it appears that at some essential things associated with: (1) intellectual ability, (2) mastery of the knowledge and skills possessed work. This shows that with the many teachers who have the ability to work with the high category will have an impact on the completion of the task well, too. With the good work it will have an impact on the achievement of high performance.

\section{SEM Test Results}

Table 6: Test results analysis of teacher empowerment that include educational qualifications, training and

\begin{tabular}{|c|l|c|c|c|c|c|}
\hline No & \multicolumn{1}{|c|}{ Variable } & $\begin{array}{c}\text { Co- } \\
\text { eficien- } \\
\text { cy }\end{array}$ & SE & $\begin{array}{c}\text { CR } \\
>1,96\end{array}$ & $\begin{array}{c}\text { Probabi- } \\
\text { lity } \\
<0.05\end{array}$ & Result \\
\hline 1 & Performa - education & 2.36 & 0.258 & 2.815 & 0.004 & significant \\
\hline 2 & Performa - training & 1.24 & 0.09 & 2.326 & 0.013 & significant \\
\hline 3 & Performa - upgrading & 0.68 & 0.502 & 1.98 & 0.06 & significant \\
\hline 4 & Qualility - education & 0.89 & 0.392 & 1.97 & 0.06 & significant \\
\hline 5 & Quality - training & 2.56 & 0.56 & 2.812 & 0.007 & significant \\
\hline 6 & Quality - upgrading & 0.03 & & & & No- \\
significant
\end{tabular}

Sources: primary data procecing

Judging from the above data, the probability of CR and its significance on the significance level can be found that the effect of empowerment that include educational qualifications, training, upgrading of teachers affect teacher performance and quality of Education in Elementary School City of Surabaya, as follows:

1. Educational qualifications of teachers have positive influence on the performance of teachers, it means that hypothesis is accepted.

2. Training preparation of the learning device has a positive effect on teacher performance, means the hypothesis is accepted

3. Upgrading to write scientific papers to the teachers have positive influence on the performance of teachers, it means that hypothesis is accepted.

4. Teacher education qualifications have a positive influence on the quality of education at the elementary school in Surabaya, it means that hypothesis is accepted.

5. Training the learning positively affected the quality of education at the elementary school in Surabaya, it means that hypothesis is accepted.

6. Upgrading to write scientific papers on the teacher does not affect the quality of education at the elementary school in Surabaya, it means that the hypothesis is rejected.

7. Empowerment of teachers has a positive effect on the quality of education at the elementary school in Surabaya mean hypothesis is accepted.

8. The most dominant variables influence the empowerment of teachers is the education and training qualifications, while the most dominant influence the quality of education is empowerment.

\section{Analysis of Research Results}

The analysis of exposure data do based on empirical and theoretical findings and previous studies relevant to the research conducted. The discussion is intended to explain the appropriateness and relevance of each dependent variable and independent variables. 
From the tests using the program AMOS 4.0 via the analysis of SEM (Structural Equation Modelling), test results of both models through the overall test and measurement test can be drawn that the multilevel model can explain the phenomenon of quality of education in elementary schools in Surabaya in several important aspects.The results of this study gives an answer that is very good multilevel model to explain the business model of empowering teachers to improve the quality of education at the elementary school in Surabaya, or accept the hypothesis.

By analyzing the effect of empowerment that include educational qualifications, training and upgrading of learning scientific writings on teacher performance and quality of Education in Primary Schools Surabaya expected us to have developed an understanding that the empowerment of teachers will affect the performance of teachers in akhirya can affect the quality Elementary education in the city of Surabaya.

In the current study found a model that links the five variables proposed in the conceptual model. The five variables include: Qualifications Education, Training Device Development Learning, Upgrading writing scientific papers, Performance and Quality of Teacher Education. Indicators of the five variables identified, the researchers eliminated one indicator because it does not qualify loading factor, an indicator of educational quality variable is the value of semester. So that indicators can be used as a measure of the variables are as follows:

1. Education variable is measured through indicators: Highschool, Diploma1, Diploma2, Diploma3, Graduate, two indicators are jointly able to explain the variable. Of the two indicators are most able to explain the variable is a formal education (S1).

2. Training variables measured by indicators: Development of syllabus, lesson plans, Devices Learning. All three indicators are jointly able to explain the variable and of these three indicators were the most able to explain the variable is the preparation of training syllabus and preparation of planing and the most recent is a learning device.

3. Upgrading of teacher variables measured through indicators: activity inservice classroom action research (CAR) and innovative learning. The indicators are jointly able to explain the variables of these indicators are best able to explain the variable is a variable is an innovative learning model development activities.

4. Teacher performance variables measured through indicators: knowledge, attitudes and skills of teachers. All three indicators are jointly able to explain the variable and of these three indicators were the most able to explain the variable is the knowledge and attitudes and skills.

5. The variable quality of education is measured through indicators: The quality and quantity of learning value. Both indicators are jointly able to explain the variable and the two indicators are the most capable of explaining the value of variable quality and quantity of learning.

In this study in addition to finding a new model as mentioned above, also found the influence of the variable effects of empowerment that include educational qualifications, training and upgrading of teachers affects the performance of teachers and quality education in an elementary school in Surabaya as the results of hypothesis testing. An explanation of the effect of empowerment variables, including educational qualifications, training and upgrading of teachers on the performance of teachers and quality education in Surabaya City Elementary School are as follows:

The influence of empowerment that includes: educational qualifications, training and upgrading of the teacher against teacher performance. From the results of descriptive analysis found elementary school teachers in the city of Surabaya, in general have a high performance in the criteria. The high performance of teachers is supported by the empowerment of teachers, including educational qualifications, training and upgrading as its attributes. Through the analysis of SEM (Structural Equation Modelling) found that, teacher performance is influenced by the empowerment of potential teachers.

From the above test results obtained that the three indicators that can be used as a measure of empowerment in explaining variables namely: educational qualifications, training, and refresher courses, three indicators are jointly able to explain the variables of empowerment, of the three indicators are most able to explain is educational qualifications, followed by your username and inservice training for teachers. Can be concluded that the test results with the analysis of SEM (Structural Equation Modelling) program AMOS 4.0 shows that empowerment is jointly positive effect on teacher performance. This analysis, in particular the empowerment has three indicators, namely: educational qualifications, training, learning device, upgrading of teachers. All three indicators are jointly able to explain the variables of empowerment, of the three indicators are most able to explain the educational qualifications, followed by training your username, then the most recent scientific work is the upgrading of teachers. It is meant to enhance the empowerment of teachers in primary schools need improvement Surabaya educational qualifications, followed by adequate training and refresher courses, upgrading courses should be in accordance with its activity. The influence of empowerment that include; educational qualifications, training, upgrading of teachers against the quality of education From the results of descriptive analysis found that the quality of education in primary schools in Surabaya express the quality of education in the high category while the remaining low to the indicators of the quality and quantity. 
From the results of SEM analysis of indicators that can explain the variable quality of education are: the value of the national exams and the final school exams. Both indicators are jointly able to explain and both indicators are best able to explain is the quality value and quantity of learning.

\section{Conclusion}

Based on the results of research and discussion that has been done above, can be summed up as follows:

1. Empowerment of teachers' abilities that include an increase in educational qualifications, training, preparation of syllabi and lesson plans, as well as the upgrading of the teachers have positive influence on the performance of teachers.

2. Empowerment of teachers' abilities that include an increase in educational qualifications, training, preparation of syllabi and lesson plans, as well as the upgrading of scientific writings influenced positively to the quality of education.

3. Teacher performance (through the indicators of knowledge, attitudes, skills) positive influence on the quality of education (quality and quantity of the study). Performance of teachers has an important role in influencing education quality improvement at the elementary school in Surabaya.

\section{Suggestions}

Some suggestions put forward in this study, among others:

First, the educational qualifications of all elementary school teachers in the city of Surabaya need to be synchronized to Strata 1. Improved teacher education qualification should be pursued because the teacher's performance is affected by teacher empowerment including education qualification.

Secondly, there needs periodic training to enhance teachers' ability in formulating the syllabus and lesson plans and teaching tools, because such training can improve the performance of teachers in planning and implementing learning.

Third, the upgrading of teachers about writing scientific papers and innovative learning needs to be given to the teacher, because it may indirectly improve its performance in implementing the learning.

\section{References}

[1] Coombs, PH. 2005. The World Crisis in Education. New York: Oxford University Press

[2] Deckey J. \& Adam, H. 1995. Basic Principles of Student Teaching. New Jersey: Prentice-Hall, Inc.

[3] Depdiknas. 2006. Three Planning of Development National Education System Jakarta: Depdiknas.

[4] Diknas Kota Surabaya. 2009. Handbook Educational in 2009 year. Surabaya: Diknas Kota Surabaya.

[5] Eaglen, Andrew et al. 2 000. Modelling the benefits of training to business performance in leisure retailing. Strategic Change. Aug. 2000. Vol. 9, iss. 5; Ferdinand, Augusty. 2000. Structural Equation Modelling. AMOS 4.0. Semarang: University Press UNDIP

[6] Furtwengler, D. 2002. Performance Assessment. Yogyakarta: Andi Haris, Richard. 2002. Personnel Administration in Education (3rd). Boston: Ally and Bacon Inc.

[7] International Education, 2000. Highlights from the Second World Congress of Education International. Washington DC: July 2000

[8] Jerome S. Arcaro. 2005. Quality in Education: An Implementation Handbook.

[9] New York: St. Lucie, Press.

[10] Langbein, Laura Irwin. 2002. Discovering Whether Programs Work: A Guide to Stastistical Methods For Program Evaluation. Santa Monica: Goodyear Pub. Company Leap, T.L, and Crino, M.D, 2002. Personnel / Human Resources Management.

[11] New York: Macmillan Publishing Company.

[12] Mangkunegoro. 2005. Performance Evaluation of Human Resources (HR).

[13] Jakarta: Refika Aditama.

[14] Sahudi. 2009. Refresher Courses and Advanced Studies for Teachers in the city of Surabaya. Suarabaya: Dinas Pendidikan Kota SurabayaSteers, Richard M. 2001. Motivation and Work Behavior. New York: McGraw- Hili, Inc.

[15] Supriyono. 1989. Human Resource Management. New York: Center for Literacy Development. Tilaar, H.A.R. 2002. Educational Problematic . Jakarta: Rineka Cipta.

[16] Undang-Undang Nomor 20 Tahun 2003. National Education System. Bandung: Umbara

[17] Undang-Undang Nomor 14 tahun 2005 About Teacher and Lecture. Bandung: Umbara

[18] UNESCO. 2002. Financing Education: Investment and Return (Analysis of the World Education Indicators 2002. Paris: UNESCO Institute for Statistics UNESCO - UNDP. 1997. Basic Educational for Impowerment of the Poor. Bangkok: UNESCOPROAP.

[19] World Bank. 2003. Education in Indonesia: From Crisis to Recovery. Washington DC: East Asia and Pacific Regional Office. 